\title{
MODELO LÓGICO PARA ANÁLISE DE POLÍTICAS PÚBLICAS EM PERSPECTIVA HISTÓRICA
}

\author{
Cleandro Krause
}

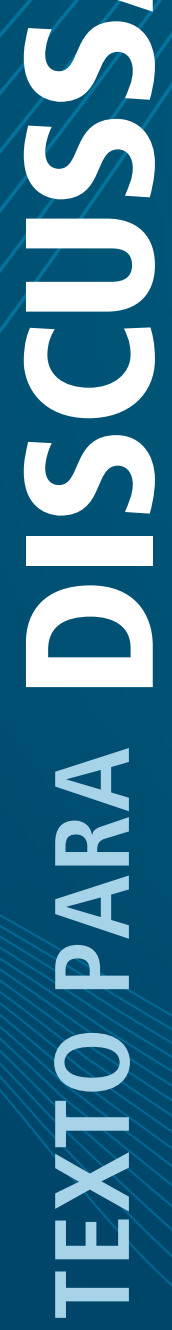





\section{TEXTO PARA DISCUSSÃO}

Rio de Janeiro, julho de 2020

\section{MODELO LÓGICO PARA ANÁLISE DE POLÍTICAS PÚBLICAS EM PERSPECTIVA HISTÓRICA}

Cleandro Krause ${ }^{1}$

1. Técnico de planejamento e pesquisa na Diretoria de Estudos e Políticas Regionais, Urbanas e Ambientais (Dirur) do Ipea. 


\section{Governo Federal}

Ministério da Economia

Ministro Paulo Guedes

\section{Texto para Discussão}

Publicação seriada que divulga resultados de estudos e pesquisas em desenvolvimento pelo Ipea com o objetivo de fomentar o debate e oferecer subsídios à formulação e avaliação de políticas públicas.

(C) Instituto de Pesquisa Econômica Aplicada - ipea 2020

Fundação pública vinculada ao Ministério da Economia o Ipea fornece suporte técnico e institucional às ações governamentais - possibilitando a formulação de inúmeras políticas públicas e programas de desenvolvimento brasileiros - e disponibiliza, para a sociedade, pesquisas e estudos realizados por seus técnicos.

Presidente

Carlos von Doellinger

Diretor de Desenvolvimento Institucional Manoel Rodrigues Junior

Diretora de Estudos e Políticas do Estado, das Instituições e da Democracia

Flávia de Holanda Schmidt

Diretor de Estudos e Políticas Macroeconômicas José Ronaldo de Castro Souza Júnior

Diretor de Estudos e Políticas Regionais, Urbanas e Ambientais

Nilo Luiz Saccaro Júnior

Diretor de Estudos e Políticas Setoriais de Inovação e Infraestrutura

André Tortato Rauen

Diretora de Estudos e Políticas Sociais Lenita Maria Turchi

Diretor de Estudos e Relações Econômicas e Políticas Internacionais

Ivan Tiago Machado Oliveira

Assessora-chefe de Imprensa e Comunicação Mylena Fiori

Ouvidoria: http://www.ipea.gov.br/ouvidoria URL: http://www.ipea.gov.br

Texto para discussão / Instituto de Pesquisa Econômica Aplicada.- Brasília : Rio de Janeiro : Ipea, 1990-

ISSN 1415-4765

1.Brasil. 2.Aspectos Econômicos. 3.Aspectos Sociais. I. Instituto de Pesquisa Econômica Aplicada.

CDD 330.908

DOI: http://dx.doi.org/10.38116/td2572

As publicações do Ipea estão disponíveis para download gratuito nos formatos PDF (todas) e EPUB (livros e periódicos).

Acesse: http://www.ipea.gov.br/portal/publicacoes

As opiniões emitidas nesta publicação são de exclusiva e inteira responsabilidade dos autores, não exprimindo, necessariamente, o ponto de vista do Instituto de Pesquisa Econômica Aplicada ou do Ministério da Economia.

É permitida a reprodução deste texto e dos dados nele contidos, desde que citada a fonte. Reproduções para fins comerciais são proibidas. 


\section{SUMÁRIO}

SINOPSE

ABSTRACT

1 INTRODUÇÃO

7

2 ANTECEDENTES DA AVALIAÇÃO DE POLÍTICAS PÚBLICAS POR MEIO DE MODELOS LÓGICOS

3 O MÉTODO DO MODELO LÓGICO DE REFERÊNCIA

4 APONTAMENTOS PARA UM PROBLEMA URBANO E SEU RESPECTIVO PROGRAMA:A CIDADE DE PORTO ALEGRE NA DÉCADA DE 1930

5 A ELABORAÇÃO DE UM MODELO LÓGICO RETROSPECTIVO .

6 ANÁLISE DE VULNERABILIDADE DO MODELO LÓGICO DO PROGRAMA DE CIRCULAÇÃO

7 CONSIDERAÇÕES FINAIS SOBRE APLICAÇÕES RETROSPECTIVAS DO MODELO LÓGICO 



\section{SINOPSE}

Este trabalho propóe uma representação hipotética de uma política pública em perspectiva histórica, conforme teria sido realizada na modernização da cidade de Porto Alegre, no final da década de 1920 até a decretação do Estado Novo em 1937. O caso concreto foi analisado na tese de doutorado em planejamento urbano e regional defendida pelo autor, destacando-se aqui o recorte metodológico relativo ao uso do método do modelo lógico de referência do Ipea para a análise de um problema/programa de circulaçáo urbana de pessoas e mercadorias. O exercício apresentado compreende os três componentes desse modelo: uma explicação do problema e as referências básicas do programa; uma estruturação do programa para alcance de resultados esperados; e a identificação de fatores relevantes de contexto. As evidências para a elaboração dos três componentes foram buscadas em fontes históricas, que também apoiaram uma análise de vulnerabilidade do modelo lógico do programa de circulação, de modo a explicar os motivos pelos quais a estruturação do programa não teria possibilitado o tratamento mais adequado das causas do problema identificado. Por fim, apresentam-se consideraçóes sobre aplicaçôes retrospectivas do modelo lógico, que podem agregar conhecimentos sobre os atos concretos da implementação de políticas públicas no passado e, assim, possibilitar explicaçóes mais robustas para os problemas que persistem e devem ser enfrentados por novos programas no presente.

Palavras-chave: problemas urbanos; circulaçáo urbana; modelo lógico.

\section{ABSTRACT}

This paper proposes a hypothetical representation of a policy seen in historical perspective. The modernization of the city of Porto Alegre, in the south of Brazil, from the end of the 1920s until 1937 was the empirical object of the author's PhD thesis in Urban and Regional Planning. Here we highlight its methodological framework, namely a logical model developed at the Institute for Applied Economic Research (Ipea), here applied for the outline of an urban circulation problem/program. Such configuration includes the three components of the logical model: an explanation of the problem and the program's basic references; the program's structuration towards the achievement of desired outcomes; and the identification of relevant factors of context. We sought evidence for the representation of the three components in historical sources, which have also supported a vulnerability analysis of the program's logical model. Such analysis permits 
to explain why the program's structuration would not have allocated the most adequate treatment to the problem's causes. We finally present considerations on retrospective uses of the logical model, which may aggregate knowledge on concrete acts of policy implementation in the past, in order to provide more robust explanations of problems that persist and must be tackled by new programs in the present.

Keywords: urban problems; urban circulation; logical model. 
Assim como todo cientista (...), o historiador escolhe e tria. Em uma palavra, analisa.

Marc Bloch

É-nos impossivel separar o trigo do joio, porque o discurso recorta e modela sobre si mesmo esse núcleo que constitui o seu objeto.

Paul Veyne $e^{2}$

\section{INTRODUÇÃO}

Como lidar com a indisponibilidade ou a ocultação de informaçóes sobre os processos decisórios das políticas públicas? Como proceder quando os objetos que se quer pesquisar não se mostram diretamente, por não poderem ser separados dos quadros formais por meio dos quais os conhecemos, ou seja, como afirma Michel Foucault, do discurso? Afinal, mesmo as evidências trazidas pela ciência e pelas técnicas são veiculadas pelo "invólucro" de alguma representação necessária, ou de uma interpretação interessada.

Se essa separação é mesmo impossível, resta prosseguir na análise "apalpando" os discursos/objetos, de modo a tentar inferir qual seria o conteúdo do seu núcleo. Sua análise, portanto, exigirá a elaboração de classificaçóes adequadas a seus propósitos, restando ao pesquisador experimentá-las, revisá-las e flexibilizá-las, em uma postura que pode ser considerada ativa ou construtiva.

Um dos caminhos de análise testados na pesquisa de doutorado em planejamento urbano e regional de Krause (2019) foi a construçáo de uma representação de um problema urbano que teria motivado açóes do poder público e da sociedade civil organizada, mediante um programa hipotético que também foi delineado a partir de evidências de sua existência obtidas de um estudo de caso concreto. $\mathrm{O}$ método para essa construçáo (ou reconstrução) já havia sido utilizado pelo autor, que, junto a outros pesquisadores, fizera parte de equipes de pesquisa no Ipea para executar tarefas de avaliação de políticas públicas.

1. Bloch, M. Apologia da história, ou o ofício de historiador. Rio de Janeiro: Zahar, 2001. p. 128.

2. Veyne, P. Foucault: o pensamento, a pessoa. Lisboa: Texto e Grafia, 2009. p. 55.

3. Para uma análise do que Foucault entendia como discurso, ver Veyne (2009). 
A contribuição deste trabalho situa-se, assim, entre os âmbitos acadêmico e governamental, em um esforço de produzir conhecimento que seja útil à ação. Por um lado, almeja-se difundir e facilitar a compreensão de um método de pesquisa já usual para a formulação ou revisão de políticas públicas, mas ainda pouco utilizado na pesquisa acadêmica; por outro, quer-se avaliar as possibilidades e limitaçóes do próprio método de pesquisa, após sua "exposição" ao ambiente acadêmico.

Parte-se da premissa de que as políticas públicas possam se desenvolver em um período que náo se resuma à duração do programa que se quer, em algum momento, avaliar. Ao contrário, a versão mais recente de um programa ou projeto governamental estaria assentada sobre uma acumulação histórica de políticas públicas - incluindo sua própria ausência, parcialidade, fragmentação etc. - que poderia ser responsabilizada, em alguma medida, pela existência da situação inicial a ser enfrentada por um novo programa ou projeto. Entende-se que o desenvolvimento de um método que possibilite esmiuçar esses antecedentes possa se constituir em contribuição relevante para o conhecimento mais sólido de conteúdos que se classifiquem, lato sensu, como políticas públicas. ${ }^{4}$

Para tanto, este trabalho apresenta, na próxima seção, antecedentes da avaliação de políticas públicas por meio do método escolhido - o modelo lógico de referência do Ipea. Na terceira seção, são explicados em detalhe o método e seus componentes, do modo como foram concebidos pelas autoras da obra de referência utilizada (Cassiolato e Gueresi, 2010). A quarta seção resume o caso pesquisado, isto é, a cidade de Porto Alegre, durante a década de 1930, compreendendo os temas urbanos que atraíam mais atenção e os atores governamentais e não governamentais responsáveis por uma construção social de problemas urbanos. A quinta seção apresenta a elaboração de um modelo lógico retrospectivo, também segundo os componentes enumerados na obra de referência citada, buscando evidências de um problema urbano e reunindo de modo abrangente, em uma estrutura lógica, os fatos, ou melhor, os objetos/discursos que servem como evidência da existência do respectivo programa. $\mathrm{Na}$ sexta seção, realiza-se uma análise de vulnerabilidade do modelo lógico do programa em questão - o que é facilitado pelo transcurso do tempo e, portanto,

4. Neste trabalho, utiliza-se o termo políticas públicas no sentido de policy, ou seja, a dimensão material referente aos "conteúdos concretos, isto é, à configuração dos programas políticos, aos problemas técnicos e ao conteúdo material das decisões políticas" (Frey, 2000, p. 217), que se entrelaça às dimensões institucional, polity, e processual, politics, que configuram, conjuntamente, policy analysis. Dado o recorte elaborado, privilegia-se a primeira dimensão em detrimento das demais. 
pela obtenção de indícios de que a representação do problema urbano, conforme reconstituída pelo modelo, teria ignorado certos aspectos da realidade, eventualmente comprometendo o funcionamento do programa conforme pretendido. Por fim, a última seção, de consideraçôes finais, alerta sobre cuidados gerais a serem tomados em aplicaçóes retrospectivas do método do modelo lógico.

\section{ANTECEDENTES DA AVALIAÇÃO DE POLÍTICAS PÚBLICAS POR MEIO DE MODELOS LÓGICOS}

Técnicos do Ipea vêm organizando avaliaçôes de programas governamentais desde a década de 1970, tendo promovido o desenvolvimento de modelos lógicos com essa finalidade desde 2005. Como piloto da aplicação da proposta metodológica do modelo lógico aos programas do Plano Plurianual (PPA) do governo federal, foi selecionado o programa Segundo Tempo, do Ministério do Esporte. Em 2007, a metodologia já era aplicada, em caráter experimental, a vinte programas finalísticos do PPA, e, no ano seguinte, a sua aplicação se deu em mais de cinquenta programas (Ferreira, Cassiolato e Gonzalez, 2009).

Em 2009, o Ipea firmou um convênio com a Caixa Econômica Federal para a realização de uma pesquisa no Complexo do Alemão, conjunto de favelas no Rio de Janeiro, que naquela ocasiáo era submetido a uma intervenção urbanística financiada com recursos da União, no âmbito do Programa de Aceleração do Crescimento (PAC). O plano de trabalho do convênio previu a elaboração de uma metodologia de avaliaçáa dos projetos do PAC, tomando o caso do Complexo do Alemão como piloto. Ainda que as obras compreendidas na intervenção já tivessem sido iniciadas, não havia, segundo o conhecimento das equipes técnicas da Caixa Econômica Federal e do Ipea, um projeto completo cujos elementos explicitassem premissas e estratégias da intervenção. O que havia eram documentos técnicos de engenharia e de trabalho técnico social, fragmentados conforme duas áreas de projeto distintas, a cargo de cada um dos entes executores - o governo do estado e a prefeitura municipal do Rio de Janeiro. Como náo havia uma memória sistematizada das decisóes que teriam resultado nesses documentos técnicos (o que não impediu que fatos anedóticos fossem relatados e levados em conta), representantes de todos os atores envolvidos foram reunidos em oficinas com o objetivo de resgatar uma teoria do programa para a intervenção no Complexo do Alemão. 


\section{Uma teoria do programa é aquela}

que consegue ser expressa, de forma objetiva, em resumo narrativo (uma frase ou um parágrafo) que expresse como o programa incide sobre as causas do problema, projetando seus resultados e impactos de longo prazo. Sugere-se que a teoria seja descrita informando: se (descreva o desenho do programa), então (descreva os resultados), o que então levará a (descreva os impactos) (Brasil e Ipea, 2018, p. 94).

Para representar a teoria do programa (ou, no caso do Complexo do Alemão, do projeto), foi utilizada a metodologia de modelo lógico. Genericamente, modelos lógicos são ferramentas "bastante amigáveis, intuitivas e largamente experimentadas e aprovadas” (Brasil e Ipea, 2018, p. 93) e, portanto, amplamente utilizadas em sistemas de monitoramento e avaliação de políticas públicas de diversos países.

No caso do Complexo do Alemão, tratou-se do primeiro esforço de técnicos do Ipea para organizar a avaliaçáo de um projeto individual e de características únicas, incidente sobre uma área urbana. Posteriormente, por meio de um acordo de cooperação técnica do Ipea com o Ministério das Cidades, a experiência adquirida no estudo de caso do Complexo do Alemão foi estendida e generalizada ao conjunto de intervençóes de urbanização de favelas e de saneamento integrado do PAC. Como característica em comum, esses programas já estavam em funcionamento, tendo havido repasses de recursos da União e liberação de financiamentos do governo federal aos entes executores subnacionais sem que houvesse precisão e clareza sobre a forma de avaliação que deles seria esperada - uma vez concluídas as obras e postos em funcionamento os equipamentos e serviços (avaliação de projeto) - e sobre o modo como seria avaliado o conjunto dessas intervençóes por parte do ministério gestor (avaliação de programa). ${ }^{5}$

Vale também ressaltar outra aplicação do modelo lógico, neste caso, a uma política pública municipal que já vinha sendo formulada e parcialmente implementada

5. A avaliação dos projetos do PAC, por parte dos entes executores, era obrigatória, sendo que o Ministério das Cidades já dispunha de uma matriz de indicadores que havia sido desenvolvida para as intervenções de urbanização de favelas do programa Habitar Brasil/BID (HBB). Contudo, um estudo realizado por técnicos do Ipea indicou que esse método de avaliação, conforme fora aplicado em relatórios pós-ocupação, não permitia a elaboração da metanálise (síntese estatística) esperada dos resultados dos projetos executados no âmbito do HBB, sendo sua comparação praticamente impossível. Isso motivou, a seguir, os esforços de revisão do próprio método de avaliação daquelas intervenções urbanísticas, também a cargo de técnicos do Ipea. Para mais informações, ver Balbim et al. (2012; 2013). 
na cidade de São Paulo. Desta vez, por meio de um convênio firmado entre o Ipea e aquele município, a mesma ferramenta serviu para organizar um programa de ações e critérios para avaliação dos Eixos de Estruturação da Transformação Urbana estabelecidos no Plano Diretor Estratégico (PDE), instituído em 2014. Tais eixos foram definidos como áreas de influência da rede estrutural de transportes coletivos, aptas ao adensamento construtivo e populacional, e à combinação entre usos mistos, residenciais e não residenciais. Previam-se aí, portanto, transformaçóes urbanas, tendo-se utilizado o modelo lógico para avaliar os limites e as possibilidades da aplicação de diversos instrumentos urbanísticos nessas áreas (Balbim e Krause, 2016).

Não se restringindo à infraestrutura ou às áreas urbanas, outros programas governamentais, já em funcionamento, também foram recentemente representados em modelos lógicos, de modo a explicitar a sua teoria subjacente e permitir, eventualmente, a sua revisão, por exemplo: o programa Cultura Viva (Silva e Labrea, 2014), o programa Luz para Todos (Freitas e Silveira, 2015) e o Programa de Aquisiçáo de Alimentos (Sambuichi et al., 2019).

Os esforços aqui brevemente resumidos, realizados desde 2005, compreenderam análises tanto de um problema que teria motivado a intervenção de uma política pública (programa ou projeto), como dos insumos (inputs) mobilizados para a entrega de produtos (outputs) que, por sua vez, gerariam os resultados esperados (outcomes) para mudar a situação que teria originado o problema identificado. Em todos os casos foi utilizada uma mesma versão de modelo lógico, que também orientou cursos sobre desenho de programas da Escola Nacional de Administraçáo Pública (Enap) e, mais recentemente, voltou a ser utilizada pelo governo federal para a formulação dos programas do PPA 2020-2023. Seu roteiro de elaboração é apresentado a seguir.

\section{MÉTODO DO MODELO LÓGICO DE REFERÊNCIA}

A aplicação de modelos lógicos inspira-se em um "truque da máquina" para a pesquisa nas ciências sociais, como o proposto por Becker (2011, p. 61, tradução nossa), que "obriga a não excluir elementos cruciais da situação", o qual descreve e circunscreve um problema, requerendo que "pensemos como engenheiros que querem que a máquina que desenharam faça o que supostamente deve fazer". Assim, deve-se realizar uma "engenharia reversa", de modo a "desarmar a máquina, ver como funciona, quais são suas partes e como se conectam entre si, e o que acontece dentro da caixa preta” (op. cit., p. 62, tradução nossa). 
Abrir a caixa preta exige expor suas partes e suas conexóes, pois o uso de modelos lógicos em avaliaçóes de resultados busca representar tanto as cadeias causais de um problema identificado, como os relacionamentos entre recursos, açóes, produtos e resultados de um programa que, espera-se, deverá mudar a situação que originou o problema. A representação desses relacionamentos deverá tentar, portanto, explicar um problema e, também, o resultado esperado da intervençáo da política pública. Ou seja, tratando um programa como uma hipótese - ou como uma aposta -, a avaliação "deve examinar ou testar as suposiçóes subjacentes de como o programa funciona, de modo a atingir os resultados esperados" (McLaughlin e Jordan, 2010, p. 73, tradução nossa).

A construção do modelo lógico é, por conseguinte, "uma proposta para organizar as açóes componentes de um programa de forma articulada aos resultados esperados, apresentando também as hipóteses e as ideias que dão sentido à intervenção" (Cassiolato e Gueresi, 2010, p. 4) pela política pública. Por contar com uma representação gráfica própria e conveniente, o modelo constitui "uma maneira sistemática e visual de apresentar e compartilhar a compreensão das relaçôes entre a explicação do problema, os recursos disponíveis para as açôes programadas e as mudanças ou resultados que se espera alcançar" (op. cit., p. 6).

A construção do modelo lógico compreende três componentes:

- explicação do problema e referências básicas do programa (objetivos, público-alvo e beneficiários);

- estruturaçáo do programa para alcance de resultados (resultado final e impactos); e

- identificação de fatores relevantes de contexto.

Cada componente será apresentado separadamente, em conformidade com a obra de referência (Cassiolato e Gueresi, 2010).

\subsection{Explicação do problema e referências básicas do programa}

As referências básicas apresentam o enunciado do problema e seus descritores na situação inicial. Os descritores "cumprem o papel de enumerar de forma clara os fatos que mostram que o problema existe" (Cassiolato e Gueresi, 2010, p. 9), ou seja, seus sintomas, ao mesmo tempo em que estabelecem uma linha de base para, futuramente, aferir a mudança esperada da situação inicial (idem, ibidem). As referências básicas ainda incluem 
a delimitação do campo de atuação do programa: objetivos, público-alvo e beneficiários, incluindo critérios para a seleção e priorização destes.

A forma usual para efetuar a análise do problema é a construção de uma árvore de problemas. Ela se organiza em torno de um problema central, para o qual irradiam possíveis causas e do qual emanam possíveis consequências. Este deveria ser o passo inicial, pois, ao se definir qual é o problema a ser enfrentado, "o objetivo geral é mais facilmente identificado, que é exatamente a mudança da situação do problema" (Cassiolato e Gueresi, 2010, p. 9). O esquema hipotético da figura 1 resume a forma como se representa a análise do problema.

FIGURA 1

Esquema hipotético de explicação de problema

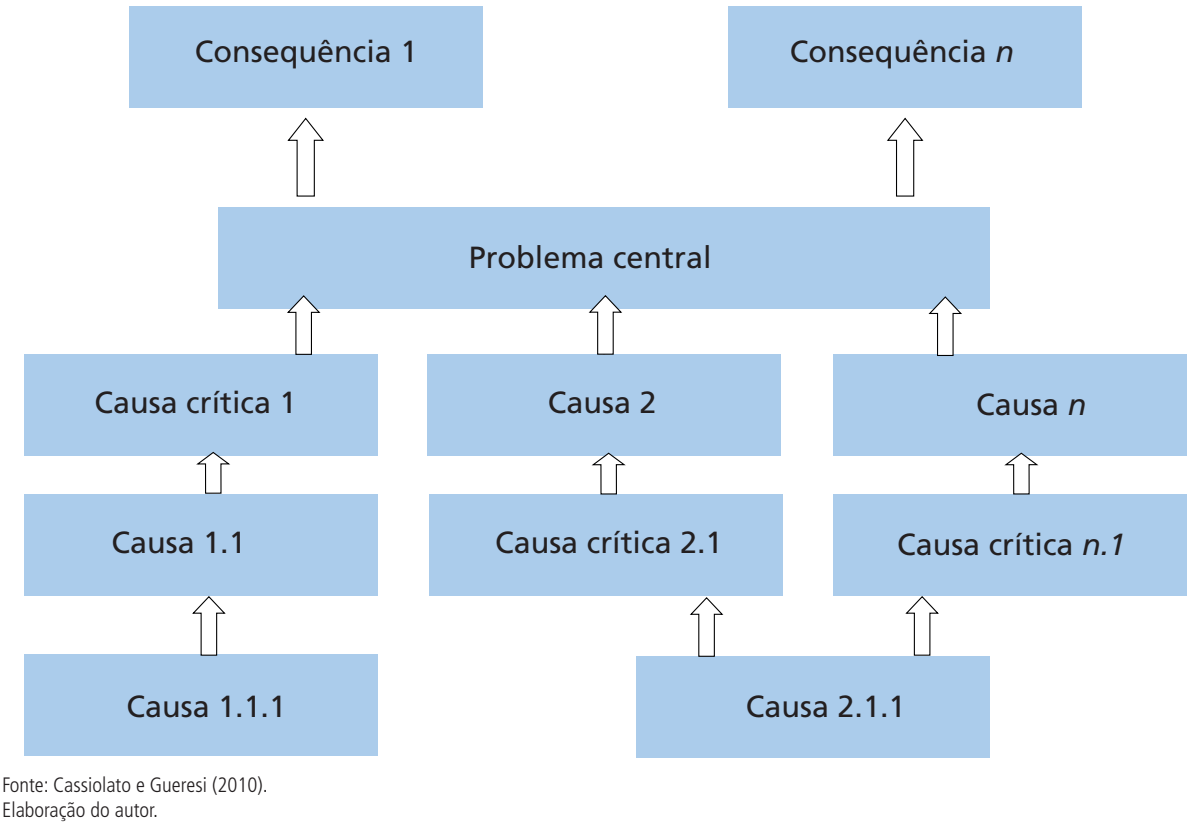

É necessária atenção à escolha do enunciado do problema central, pois “o nome de um problema (...) cria uma crença sobre quais condiçôes a política pública pode mudar, e em quais não se pode tocar" (Edelman, 1977, p. 28, tradução nossa). Há um grupo especial de causas que compóem a explicação do problema, e algumas são selecionadas como críticas para mudar a situação inicial. Sua posição nas cadeias causais permite que, ao se intervir sobre elas, outras causas sejam modificadas. Assim, as causas críticas devem cumprir três requisitos: $i$ ) ter alto impacto na mudança do problema; ii) ser um 
centro prático de ação, para que se possa agir de modo prático, efetivo e direto sobre a causa, sem a necessidade de intervir sobre uma causa decorrente na cadeia causal; e iii) ser politicamente oportuno agir sobre a causa identificada (Cassiolato e Gueresi, 2010, p. 10). Em decorrência disso, as açóes do programa devem estar orientadas para mudar as causas críticas do problema.

\subsection{Estruturação do programa para alcance de resultados}

Conforme a obra de referência,

as açóes geram produtos, que são bens ou serviços ofertados aos beneficiários do programa. Em decorrência dos produtos das açóes, os resultados intermediários evidenciam mudanças nas causas do problema e, por sua vez, levam ao resultado final esperado, que está diretamente relacionado ao objetivo do programa, refletindo a mudança no problema (Cassiolato e Gueresi, 2010, p. 10).

Esses relacionamentos estão resumidos no esquema da figura 2.

FIGURA 2

Estruturação de um programa para alcance de resultados

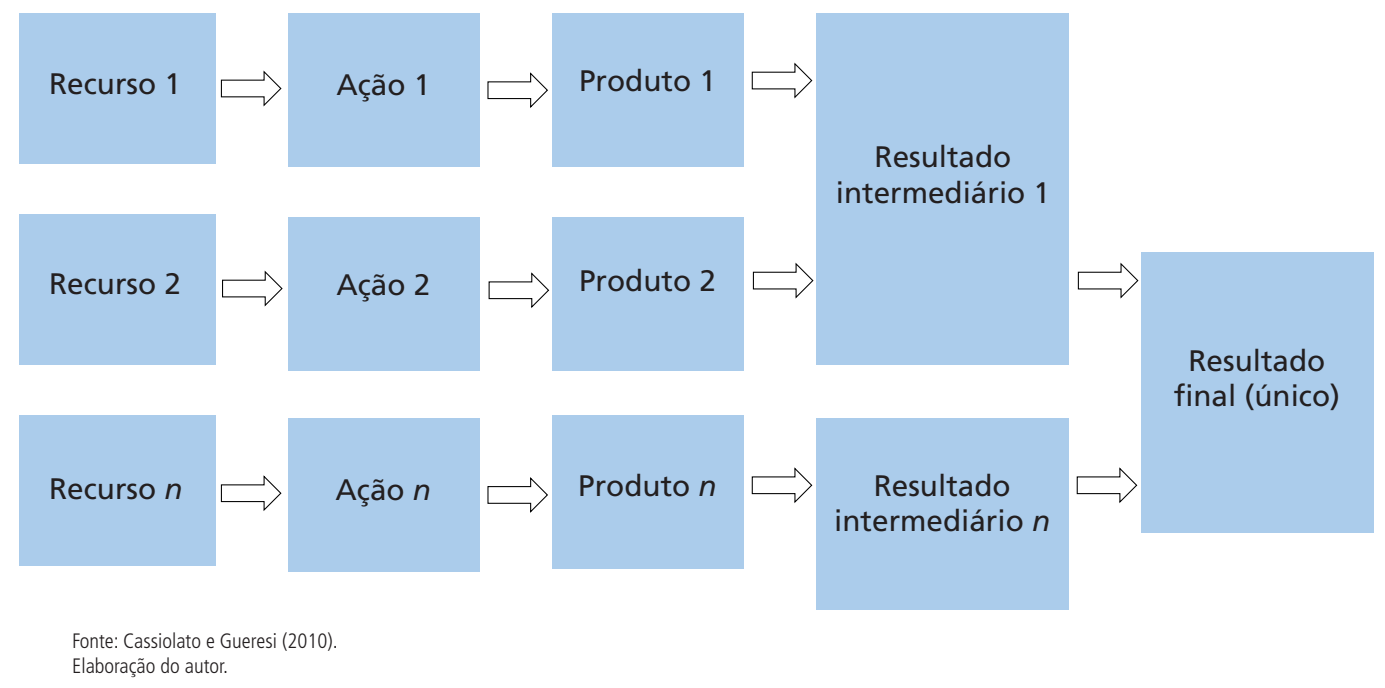

É importante que a estrutura lógica do programa traga uma representação realista dos vínculos causais, especialmente no que se refere às relaçóes entre produtos (outputs) e resultados (outcomes). Espera-se que os resultados intermediários decorram da soma dos produtos necessários e suficientes para mudar as causas críticas. 
Cabe também considerar que um dos usos possíveis do modelo lógico se refere a um exame de avaliabilidade (evaluability assessment). Neste caso, ele é uma ferramenta que pode ser aplicada antes de se decidir pela implementaçáo de um programa, ou seja, uma avaliaçáo ex ante (McLaughlin e Jordan, 2010, p. 56). O exame de avaliabilidade poderá mostrar se o programa está bem formulado para alcançar os resultados esperados. Se náo, será preciso redesenhá-lo para que possa ser avaliado por resultados. Em uma situaçáo, a análise pode mostrar, eventualmente, que há chances de o programa funcionar de modo diferente do previsto para alcançar os resultados, pois as cadeias causais da estrutura podem náo expressar os relacionamentos efetivos entre insumos, produtos e resultados. Ou seja, o modelo lógico deverá ser revisado. Em outra, é provável que a análise das cadeias causais da estrutura lógica evidencie lacunas, as quais impedirão que se efetivem os relacionamentos esperados entre insumos, produtos e resultados. Neste caso, o modelo lógico do programa também deverá ser revisado.

Por fim, para concluir a elaboração do modelo lógico, "é preciso refletir sobre as possíveis influências do contexto sobre a implementação do programa" (Cassiolato e Gueresi, 2010, p. 13).

\subsection{Identificação de fatores de contexto}

É importante uma análise do contexto de implementação do programa para identificar tanto os fatores que poderão favorecer, como os que poderão comprometer o desenvolvimento das açôes e a entrega dos respectivos produtos. Este componente da análise permite, portanto, testar as hipóteses assumidas na estruturaçáo do programa para o alcance de resultados.

Como será visto adiante, a construçáo do modelo lógico de um problema urbano histórico da cidade de Porto Alegre revelou-se um desafio pela exigência de informaçôes disponíveis para análise do contexto. Entretanto, buscou-se avançar na exploração do modelo como ferramenta de avaliação aplicável a contextos nos quais as informaçóes, tanto sobre o problema como sobre o programa, se apresentem de modo incompleto. Em outras palavras, tratou-se de interpretar indícios fragmentados de uma política pública realizada no passado, de modo a compor uma totalidade, na forma de um programa hipotético que os reconstitua - até mesmo porque é provável que os próprios agentes da política pública não tenham desenhado um programa, ou seja, não tenham explicitado sua teoria. Antes de fazer esse exercício investigativo, apresenta-se, na seçáo a seguir, o contexto que lhe serve de motivação. 


\section{APONTAMENTOS PARA UM PROBLEMA URBANO E SEU RESPECTIVO PROGRAMA:A CIDADE DE PORTO ALEGRE NA DÉCADA DE 1930}

Cabe notar que uma representaçáo abrangente de um problema e de um programa, que explicite seus nexos e os modos como se pretende atingir os objetivos, pode se mostrar contrária à maneira como aqueles usualmente são tratados pelas políticas públicas. A propósito da linguagem nelas utilizada, Edelman (1977, p. 40-41, tradução nossa) afirma que

nossos mundos políticos são segmentados, disjuntos, focalizados a cada momento em um pequeno conjunto de ansiedades, mesmo que cada "questáo" seja uma parte de um todo cada vez mais integrado (...). No lugar da habilidade de lidar com questóes em termos de seus laços lógicos e empíricos mútuos, a linguagem da política nos encoraja a vê-los e a senti-los como separados.

Tal segmentação está refletida em uma das fontes primárias utilizadas na pesquisa que fundamenta este trabalho (Krause, 2019). Trata-se dos relatórios administrativos elaborados anualmente pelos chefes do Poder Executivo do município de Porto Alegre, no período entre 1897 e 1937. Em uma continuidade administrativa que durou quarenta anos, a capital do estado do Rio Grande do Sul teve apenas três intendentes e o último deles foi nomeado prefeito em 1930, permanecendo no cargo até o final do período observado.

Nos relatórios, é certo que os intendentes faziam descriçôes exaustivas do que hoje podem ser chamados de problemas urbanos. Contudo, as soluções adotadas eram distintas, conforme as partes da cidade sobre as quais incidiam os problemas. Por exemplo, o tema do saneamento era desdobrado em seçôes separadas nos relatórios, de acordo com a soluçáo técnica adotada: i) a área mais consolidada, central e rica da cidade, onde uma rede de esgoto cloacal começou a operar em 1912, era tratada em uma seçáo denominada saneamento da cidade; ii) a área menos consolidada, correspondente, grosso modo, à zona suburbana, onde o esgoto era recolhido por um serviço de cubos ou fossas móveis, estava na seção de asseio público dos relatórios; e iii) uma área ribeirinha ocupada por população pobre e não atendida por qualquer serviço de saneamento, e que viria a ser removida quando da retificação e canalização do curso de água adjacente que, ao extravasar, causava enchentes, era objeto de uma seçấo denominada saneamento do Riacho. 
Ou seja, nesses relatórios apresentavam-se separadamente diferentes contextos e soluçōes técnicas, sem explicitar que os problemas incidentes em cada área tinham causas em comum, e sem evidenciar desigualdades de atendimento, dificultando, portanto, uma avaliaçáo conjunta do saneamento como um único problema/programa.

Além da fragmentação socioespacial das políticas públicas, o decurso do período observado na pesquisa ainda traria uma nova camada de complexidade, uma vez que sua formulaçáo passou a incluir novos atores da sociedade civil, em um movimento no qual o partido que detinha o poder em Porto Alegre e no estado - o Partido Republicano Rio-Grandense (PRR) -, protagonista da continuidade administrativa mencionada, buscou a adesão de mais fraçóes de classe à sua hegemonia. Um dos atores "convidados" a participar da gestáo de problemas urbanos foi o Rotary Club ${ }^{6}$ de Porto Alegre. Entre muitas açôes, suas campanhas miraram o tráfego de pessoas e de veículos, temas relacionados, portanto, à circulação, que ganharam relevância no pós-1930, em um momento em que o rodoviarismo já se impunha e a cidade ganhava maiores extensão e adensamento, populacional e econômico. ${ }^{7}$

O tratamento desses novos temas exigiria uma ação mais intensa sobre a superestrutura, juntando-se esta às açóes que a prefeitura já desenvolvia na infraestrutura econômica. A construção social dos problemas da cidade, no início da década de 1930, deveria incluir, dessa forma, ambos os aspectos, sendo que a elaboração hipotética que se realiza aqui leva em conta os vínculos das campanhas do Rotary Club com a administração municipal, bem como as conexôes entre as campanhas em si. Verifica-se,

6. As primeiras sedes do Rotary Club, organização de origem norte-americana, foram fundadas nas maiores cidades do Brasil, no início da década de 1920, e o urbanismo foi tema que logo recebeu a atenção do clube (Pereira, 2007). A discussão sobre a vinda de um técnico para a elaboração de um plano de remodelação para o Rio de Janeiro obteve apoio do clube, o que influiu na vinda do urbanista francês Alfred Agache em 1927 (Rezende, 2012). A mesma expectativa de elaboração de um plano de remodelação teria levado Agache a Porto Alegre, tendo-se constatado a visita do urbanista no mesmo mês (novembro de 1928) em que ocorreu a reunião de instalação do Rotary Club na cidade (Krause, 2019).

7. A análise de outras categorias do urbanismo, como o embelezamento e o saneamento, poderia resultar em explicações de problemas análogos, aplicados a outros bens de consumo coletivo. A escolha da circulação deve-se efetivamente ao reforço da ênfase a esta questão, em ações coordenadas do Rotary Club e do poder público. Em comparação, o embelezamento, categorizado como não reprodutivo pelos gestores municipais, ou seja, em atendimento a uma demanda não solvável (usufruto de parques, praças etc.), ficaria mais na alçada do Rotary, enquanto o saneamento, ao menos enquanto serviço fortemente reprodutivo pelas tarifas que podiam ser cobradas, estaria muito mais no âmbito do poder público. Um problema de circulação, considerado parcialmente reprodutivo, exigiria mais fortemente a atuação conjunta do Estado e da sociedade civil. 
assim, que as campanhas mais importantes e duradouras foram aquelas relativas aos usos do espaço público, com destaque para a mendicidade e o tráfego de pedestres. ${ }^{8}$

Para recolher dados nas fontes históricas e associar elementos dispersos do que teria sido uma política pública relativa à circulação urbana no período estudado, recorre-se aqui ao modelo epistemológico (ou paradigma) indiciário. Recorde-se que seus princípios vieram a amadurecer no final do século XIX, justamente quando "vinha surgindo uma tendência cada vez mais nítida de um controle qualitativo e minucioso sobre a sociedade por parte do poder estatal, que utilizava uma noção de indivíduo baseada, ela também, em traços mínimos e involuntários” (Ginzburg, 1989, p. 171). Diante de uma realidade que é opaca, o paradigma indiciário considera que "existem zonas privilegiadas - sinais, indícios - que permitem decifrá-la" (op. cit., p. 177), e mesmo indícios mínimos teriam sido "assumidos como elementos reveladores de fenômenos mais gerais" (op. cit., p. 178), como a visão de mundo de uma classe social. Ao discutir se tal paradigma pode ser rigoroso, Ginzburg (1989, p. 179) reconhece nele um rigor flexível, tratando-se de

formas de saber tendencialmente mudas - no sentido de que (...) suas regras náo se prestam a ser formalizadas nem ditas. Ninguém aprende o ofício de conhecedor ou de diagnosticador limitando-se a pôr em prática regras preexistentes. Nesse tipo de conhecimento entram em jogo (...) elementos imponderáveis: faro, golpe de vista, intuição.

De algum modo, o paradigma indiciário influenciaria o tratamento de um problema que exigisse classificar públicos-alvo, de maneira que estes fossem focalizados por algum programa. Em Porto Alegre, tal foi o caso dos "verdadeiros" e "falsos" mendigos, conforme terminologia utilizada tanto pelo Rotary Club, como pela prefeitura e pela polícia, no início da década de 1930. O primeiro desses públicos-alvo corresponderia aos pobres “merecedores", que deveriam receber atenção de uma organização - a Sociedade Porto-Alegrense de Auxílio aos Necessitados (SPAAN), criada por iniciativa do Rotary - responsável por centralizar a distribuição de esmolas, o que faria com que os verdadeiros mendigos, conforme esperado,

8. 0 tráfego de automóveis também era tema tratado pelo clube no âmbito de uma comissão de urbanismo. Contudo, não era visto propriamente como um incômodo, havendo pouca contestação quanto ao comportamento de motoristas, um sinal de que os sócios, até por sua alta posição social e seu grande poder aquisitivo, colocavam-se do lado dos primeiros automobilistas, interessados na livre circulação de veículos automotores. 
desocupassem o espaço público. ${ }^{9}$ Por sua vez, os falsos mendigos, supostamente tendo condiçōes de trabalhar, seriam, conforme afirmavam os agentes públicos locais, refratários ao trabalho, e buscariam beneficiar-se indevidamente da caridade - deveriam, assim, ser identificados e reprimidos pela polícia, que faria também com que eles "circulassem".

Isso denota que a política pública, discricionária em suas práticas de implementação, estava carregada de julgamentos morais sobre os indivíduos que deveriam receber cada forma de tratamento. A discricionariedade costuma decorrer das

condições sob as quais esses agentes da linha de frente desempenham suas funçôes, marcadas por objetivos ambíguos, um emaranhado de regras complexas, excesso de demanda, escassez de recursos, distância da supervisão hierárquica, e em interaçôes face a face com os destinatários da ação pública (Pires, 2019, p. 34).

Ainda conforme Pires (2019), a compreensão da implementação da política pública exigiria atenção para a atuação cotidiana desses trabalhadores da linha de frente, caso, por exemplo, dos policiais e dos fiscais de posturas municipais. No caso concreto aqui relatado, de uma pesquisa que se utilizou exclusivamente de fontes históricas, tal compreensão não poderia ter senão realização limitada. Contudo, até onde se sabe, regras para a classificação dos públicos-alvo em verdadeiros e falsos mendigos teriam sido criadas e empregadas ad hoc, sem conhecimento (e, provavelmente, sem questionamento) público.

Como a ambição da pesquisa, também seguindo o paradigma indiciário, era dar forma a um problema que possa ser compreendido em uma totalidade, supóe-se que um tratamento integrado poderia seguir uma lei do mínimo esforço. Assim, um número limitado de agentes e instituiçôes seria envolvido, o que facilitaria a troca de informaçôes entre setores do Estado e da sociedade civil interessados em uma mesma questão, de ampla repercussão na opiniáo pública.

Dois indícios apoiaram essa premissa da pesquisa: i) o presidente da comissão do Rotary Club dedicada ao tráfego urbano acumulava essa funçáo com a de presidente da instituição criada para centralizar a distribuição de esmolas aos mendigos - a citada SPAAN; e ii) houve, ao longo da década de 1930, uma crescente representaçáo de agentes públicos no Rotary, com

9. Gans (1968 apud Oliven, 1982, p. 49) explica assim o raciocínio desse julgamento: "se os pobres são merecedores, eles obviamente têm direito à admissão na sociedade afluente como iguais; se eles não são merecedores, eles não necessitam ser admitidos, ou pelo menos não até se tornarem merecedores". 
sua nomeação entre as cada vez mais numerosas classificaçóes de "governo" no quadro social do clube, incluindo o próprio servidor municipal que tinha responsabilidade pela comissão de sindicância da SPAAN, ou seja, por dirimir dúvidas de classificação dos verdadeiros e falsos mendigos. ${ }^{10}$ Estes sinais são considerados fortes para apoiar um desenho unificado do problema e do respectivo programa, conforme debatido na seção a seguir.

\section{A ELABORAÇÃO DE UM MODELO LÓGICO RETROSPECTIVO}

\subsection{Explicação do problema}

Considera-se que o método do modelo lógico serve aqui aos propósitos desejados de representação abrangente de um problema urbano e de um programa respectivo. Já foram introduzidas as referências básicas ao tratar do delineamento de públicos-alvo, que distinguiu verdadeiros e falsos mendigos, por exemplo. Além destes, uma explicação do problema, conforme demonstra a figura 3, busca enumerar outros públicos-alvo, existentes no contexto observado. Delimita-se, assim, um problema central, para o qual irradiam possíveis causas e do qual emanam possíveis consequências.

\section{FIGURA 3}

Explicação de um problema de circulação hipotético

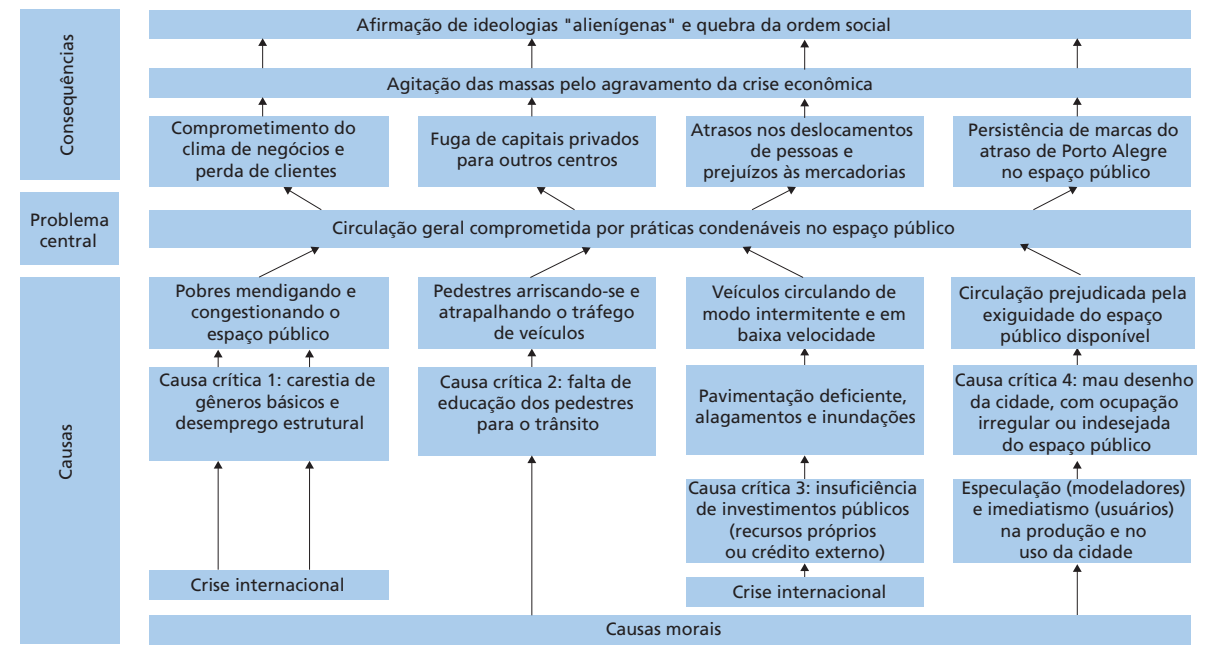

Elaboração do autor.

10. Respectivamente, os sócios do Rotary Club: i) Adel Carvalho, enquadrado pelo clube na classificação de equipamento ferroviário (carros e locomotivas); e ii) Conrado Ferrari, servidor público municipal que viria a ser nomeado prefeito, próximo ao final do Estado Novo (conforme atas conservadas no clube). 
Elabora-se o enunciado do problema central, portanto: circulação geral comprometida por práticas condenáveis no espaço público. Nesta interpretação, contribuiriam para o problema central quatro grupos de causas, cada um associado a um grupo de indivíduos que seria convertido em um público-alvo pela política pública, conforme descrito a seguir.

- O primeiro era formado pelos mendigos que, alegadamente, congestionavam os passeios. ${ }^{11}$

- O segundo era constituído pelos pedestres - especialmente os estudantes - e pelos condutores de veículos de tração animal que, em sua "imprudência”, aumentariam o risco de acidentes. ${ }^{12}$

- O terceiro grupo contemplava os condutores de veículos motorizados, cuja baixa velocidade também contribuía para uma circulação geral dificultosa, sendo que, diferentemente dos dois primeiros grupos, o indivíduo integrante deste seria visto mais como vítima do que como responsável pelo tráfego ruim.

- Por fim, um quarto grupo era integrado por usuários e modeladores do espaço urbano, incluindo tanto aqueles que, com algum imediatismo, usufruiriam dele sob formas de ocupação "condenáveis" - comércio ambulante, carroças e cavalos mal estacionados, jogos e diversóes na via pública etc. -, como aqueles agentes - proprietários fundiários e mesmo os primeiros profissionais, engenheiros e arquitetos - que teriam sido responsáveis pelas formas de urbanização pretéritas. Estâo implicadas neste último caso as formas de urbanização caracterizadas por vias com alinhamento "defeituoso", no dizer de um representante dos proprietários de imóveis em um dos logradouros mais prósperos da cidade ${ }^{13} \mathrm{em}$ 1883 , e as que teriam seguido um "sistema errôneo", expressão que o pioneiro do urbanismo local Benno Hofmann havia utilizado para criticar, em 1925,

11. 0 momento observado corresponde ao de redução drástica dos cortiços na área central de Porto Alegre, conforme demonstrado pelos registros administrativos da municipalidade. Com o correspondente deslocamento da moradia da população pobre para outras áreas da cidade, a mendicidade passaria a ser o "problema urbano" mais visível na área central. 12. A ameaça de desastres era associada por um industrial influente como A. J. Renner, sócio do Rotary, ao comportamento considerado imprevisível dos estudantes no espaço público, conforme suas falas registradas em atas conservadas no clube. 13. Conforme requerimento de João de Deos Siqueira, representando proprietários da rua Independência. Naquele requerimento, conservado no Arquivo Histórico de Porto Alegre Moysés Vellinho (AHPAMV), referente ao fundo de construção e melhoramentos do município (Porto Alegre, 1996, p. 122), os moradores reclamavam melhoramentos urbanos à Câmara Municipal. 
os arruamentos especulativos, monótonos e de exíguo e desinteressante espaço público na cidade (Hofmann, 1925). ${ }^{14}$

Esse último grupo era, certamente, mais amplo e difuso do que os anteriores, mas considera-se necessário incluí-lo na explicação do problema, antecipando sua focalização como público-alvo relevante pela política pública, que viria a desenvolver açôes em prol da assimilação das técnicas e discursos do urbanismo pela população. ${ }^{15}$

Entre as causas mais remotas do problema de circulação estaria a crise financeira internacional. Ela era uma alegação frequente para todo e qualquer imobilismo do poder público, mas também justificou açóes da municipalidade. Outras causas remotas, com alto grau de indeterminação, poderiam ser rotuladas como causas morais.

As causas podem ser organizadas em grupos ou cadeias, que se diferenciam conforme os públicos-alvo. Elas são detalhadas a seguir.

- O comportamento reprovado dos mendigos decorreria diretamente do desemprego e da carestia dos alimentos, causados, por sua vez, pela crise econômica internacional.

- Para o risco provocado pelos pedestres, a própria novidade das condiçóes de trânsito - mais intenso e mais letal, pela presença de mais veículos, cada vez maiores e mais velozes - poderia ser tida como causa imediata. No entanto, com a explicação do problema recorrendo à imprudência, esta estaria associada mais fortemente à falta de educação para o trânsito, e decorreria, portanto, do que se denominou aqui causas morais, que poderiam incluir a índole da nação ou do povo - recordando a expressão utilizada por Silvio Romero ${ }^{16}$ e, no contexto local,

14. Hofmann fez essas observações a propósito da ausência de um "plano certo" ou "projeto geral" para novos bairros de Porto Alegre. A ilustração das críticas foi feita citando loteamentos com pouquíssimos serviços urbanos, e que eram destinados à classe operária da cidade, nos quais também se instalava a maior parte dos estabelecimentos industriais à época - os atuais bairros Navegantes, São Geraldo e São João.

15. Cabe citar a Exposição de Urbanismo, realizada em Porto Alegre em 1936, com grande afluxo de público, na qual os urbanistas L. A. Ubatuba de Faria e E. P. Paiva apresentaram um plano viário e projetos para novos bairros a serem implantados em expansões urbanas. Tais propostas, conforme o jornal mantido pelo partido no poder, serviriam "para dar uma ideia do que no futuro poderá ser Porto Alegre" (Uma exposição..., 1936, p. 3). Uma campanha pelo urbanismo teria continuidade na gestão posterior, já sob a vigência do Estado Novo.

16. Intelectual influente à época, ao referir-se às pesquisas domiciliares realizadas ainda no século XIX pelo francês Frédéric Le Play, Romero atribuía a ele "os melhores trabalhos existentes sobre a índole das nações" (Romero, 1908, p. 115). E, para que se faça ideia do pensamento daquele reformador social francês, pioneiro do survey, cabe citar sua crença de que "a união indissolúvel entre a família e seu lar é a prática que exerce a mais salutar influência sobre a moralidade e o bem-estar da família operária" (Le Play, 1881 apud Guerrand, 2009, p. 357), exemplificando o ideário moralista que também seria assumido pelos gestores inspirados pelo positivismo de Auguste Comte, no Rio Grande do Sul. 
pelo jornalista e deputado Othelo Rosa, ao desaconselhar, em reunião do Rotary, uma nova campanha de trânsito, dada a baixa efetividade dos primeiros esforços do clube nesse sentido -, ou seja, aludindo a comportamentos que não seguiriam parâmetros de racionalidade esperados ou desejados.

- Relativamente aos condutores, a baixa velocidade resultante da circulaçáo dos veículos motorizados, especialmente na área central, estaria ligada primordialmente a causas relacionadas à infraestrutura econômica: pavimentação deficiente e ocorrências de alagamentos e inundaçóes eram causas históricas, agravadas pela baixa capacidade de investimento do município, muito dependente de empréstimos externos, sendo que a obtenção destes, no pós-1930, mostrava-se ainda mais difícil, dada a escassez de crédito internacional.

- Finalmente, o mau desenho da cidade e a ocupaçáo irregular ou indesejada do espaço público, que determinavam a exiguidade do espaço público disponivel, poderiam ter, como causas, atitudes associadas ao desrespeito das normas municipais (todo o conjunto de códigos de posturas e de construçôes que já havia) e também, remotamente, à "índole do povo". Ambos os subgrupos de usuários e modeladores do espaço urbano teriam em comum o desejo de ganhos extraordinários dos que se apropriavam, mas não pagavam devidamente pelo espaço utilizado (valor de uso), e dos loteadores/especuladores (valor de troca).

Dando sequência a essa interpretação, elencam-se a seguir quatro consequências mais imediatas que poderiam advir da persistência de um problema de circulaçăo na cidade.

- O comprometimento de um bom clima de negócios e a perda de clientes por seu afastamento da área de comércio mais intenso, seja pela presença dos mendigos, considerada repulsiva, seja pela própria restriçấo física do acesso dos clientes a ela. ${ }^{17}$

- A ameaça da fuga de capitais privados da cidade, especialmente em direçáo a centros maiores, como Rio de Janeiro e Sáo Paulo, que era citada como justificativa para que a municipalidade desse andamento a investimentos públicos na área central, mantendo-se a percepção desse risco no início da década seguinte. ${ }^{18}$

17. Seria, assim, comprometida a proximidade aos clientes, o "mais importante recurso locacional dos estabelecimentos comerciais" (Logan e Molotch, 2007, p. 21, tradução nossa).

18. Em 1942, o urbanista Edvaldo P. Paiva sugeria que "o ritmo de desenvolvimento das construções, em nossa cidade, podia ser bastante maior, principalmente no tocante às grandes construções de apartamentos e escritórios. Nota-se extrema lentidão na reconstrução das faces da avenida Borges, por exemplo. A razão disso é que os capitalistas daqui preferem empregar seus capitais em construções no Rio de Janeiro e São Paulo, onde o custo do material é mais baixo e maior a renda - sendo, portanto, maior o juro obtido pelo capital empregado" (Paiva, 1942, p. 121). No ano seguinte, as alíquotas do imposto predial que haviam sido praticadas na gestão do prefeito Alberto Bins seriam responsabilizadas pela "evasão de capitais, que iam buscar melhor retribuição noutros meios, em particular Rio e São Paulo" (Silva e Paiva, 1943, p. 83). 
- Os prejuízos econômicos dos atrasos nos deslocamentos de empregados e dos danos às mercadorias durante seu transporte, que também seriam uma consequência das más condiçôes das vias.

- A manutenção da especulação na produção do espaço urbano, e do imediatismo de seu uso, que, em ambos os casos, perpetuaria uma imagem do "atraso" de Porto Alegre em relação às maiores cidades do país e aos centros vizinhos do Prata Buenos Aires e Montevidéu -, que lhe serviam como referências para comparação.

Todas essas consequências, em maior ou menor grau, seriam temidas pelas camadas de mais alta renda da cidade - incluindo, evidentemente, os sócios do Rotary Club -, e poderiam contribuir conjuntamente para uma consequência indesejada, no sentido da piora da própria situação econômica dessas camadas no pós-1930. Por sua vez, além de aumentar os prejuízos (ou diminuir os lucros) dos empresários, a manutenção da crise econômica, a carestia e o desemprego poderiam combinar-se à agitaçáo das massas, vistas (ou antevistas, portanto, temidas) como cada vez mais propensas à revolta, em um momento politicamente sensível, que antecedeu a decretação do Estado Novo, em 1937. Finalmente, a absorção de "ideologias exóticas" pelas massas, sendo certamente o comunismo a maior "ameaça”, poderia levar à quebra da ordem social. A ansiedade diante dessa ameaça seria intensificada pela eclosão da guerra em momento posterior, e ainda receberia atenção, por exemplo, do urbanista Arnaldo Gladosch e do Conselho do Plano Diretor em 1940, apoiando a menção desta consequência, no exercício investigativo aqui apresentado, como um resultado político e ideológico possível, ainda que remoto, de um problema cuja centralidade estaria no âmbito do urbanismo. ${ }^{19}$

Antes de passar do problema ao programa, avalia-se que as causas referentes à carestia e ao desemprego; à falta de educação para o trânsito; à insuficiência dos investimentos públicos; e às más práticas de desenho e de ocupação do espaço público seriam adequadamente classificadas como causas críticas, por terem em comum a identificação

19. Na sétima reunião do Conselho do Plano Diretor, em 2 de julho de 1940, o urbanista carioca Gladosch, auxiliar de Alfred Agache no plano para o Rio de Janeiro, e contratado pela municipalidade para a organização dos trabalhos do Plano Diretor de Porto Alegre, fez uma longa introdução. Nela, ele considerou as más condições de habitação que "já conduziram centenas de milhares à ruína física e moral, sendo ela uma das principais fontes do descontentamento popular, constituindo, assim, os focos de ideias e tendências exóticas, que são, hoje, um dos mais sérios perigos para todas as nações cultas", sendo, portanto, "a missão mais nobre do urbanismo moderno (...) libertar a população humana desta miséria, torná-la novamente sã, capaz e disposta para o trabalho" (Silva e Paiva, 1943, p. 179). Implicitamente, Gladosch situou a ocorrência em uma área que seria uma "ameaça" à cidade, pois em seguida apresentou o traçado definitivo do seu plano diretor, no que tocava à área que incluía o Riacho e a Praia de Belas, habitada por população pobre, mas distinta dos operários da indústria que habitavam os bairros Navegantes e São João, de baixa renda. 
conspícua dos responsáveis diretos (impacto na mudança do problema), estarem no raio de ação prática tanto do poder público como da sociedade civil, e por serem reafirmadas publicamente como problema cada vez mais grave (oportunidade política de ação).

Reafirmando-se a redação dada ao problema central, ela busca circunscrever aquilo que estaria dentro das possibilidades de ação da política pública. Ou seja, o poder público (a municipalidade) e a sociedade civil (representada aqui pelo Rotary Club) teriam meios para intervir direta ou indiretamente na circulação e nas práticas no espaço público. É óbvio, contudo, que a política pública local náo teria capacidade deafetar a ordem econômica mundial e, certamente, não desejaria intervir profundamente na ordem econômica local, tendo em vista os interesses diretos dos seus principais agentes econômicos, bem representados no Rotary Club. Assim, reitera-se que as causas econômicas (resumidas na crise internacional) seriam remotas e dificilmente atacáveis. Em contrapartida, as muitas consequências econômicas da persistência do problema, que poderiam ter desdobramentos graves para os mesmos agentes, justificariam a atenção da política pública.

\subsection{Estruturação de um programa para alcance de resultados}

Em uma proposta de estruturação de um programa de circulação, as açóes englobariam mudanças tanto na infra como na superestrutura. Procurou-se desdobrar essas açóes de modo que cada uma correspondesse a um produto. Esta etapa inclui, de saída, açóes e produtos que não estariam inicialmente associados às respectivas causas do problema, envolvendo a própria categorização distinta de públicos-alvo. Esta categorização tomou a forma de uma ação preparatória, que seria necessária e poderia ser vista como racional, mesmo porque viria a delimitar melhor o problema, compreendendo a divisão entre verdadeiros e falsos mendigos (separando, ainda, os desempregados conjunturais), aos quais seriam administrados tratamentos distintos.

Uma interpretação para o programa aqui em discussão está apresentada no diagrama da figura 4. Nele, dispóem-se as açóes e os produtos cuja existência pôde ser verificada em pesquisa documental (Krause, 2019), vinculando-os a resultados que foram elaborados de modo a refletir transformaçóes desejadas na realidade, em conformidade com os discursos também encontrados na pesquisa. Para melhor articular a estruturação lógica do programa com a explicação do problema, as causas críticas encontram-se reproduzidas no diagrama. 
FIGURA 4

Estruturação de um programa de circulação para alcance de resultados

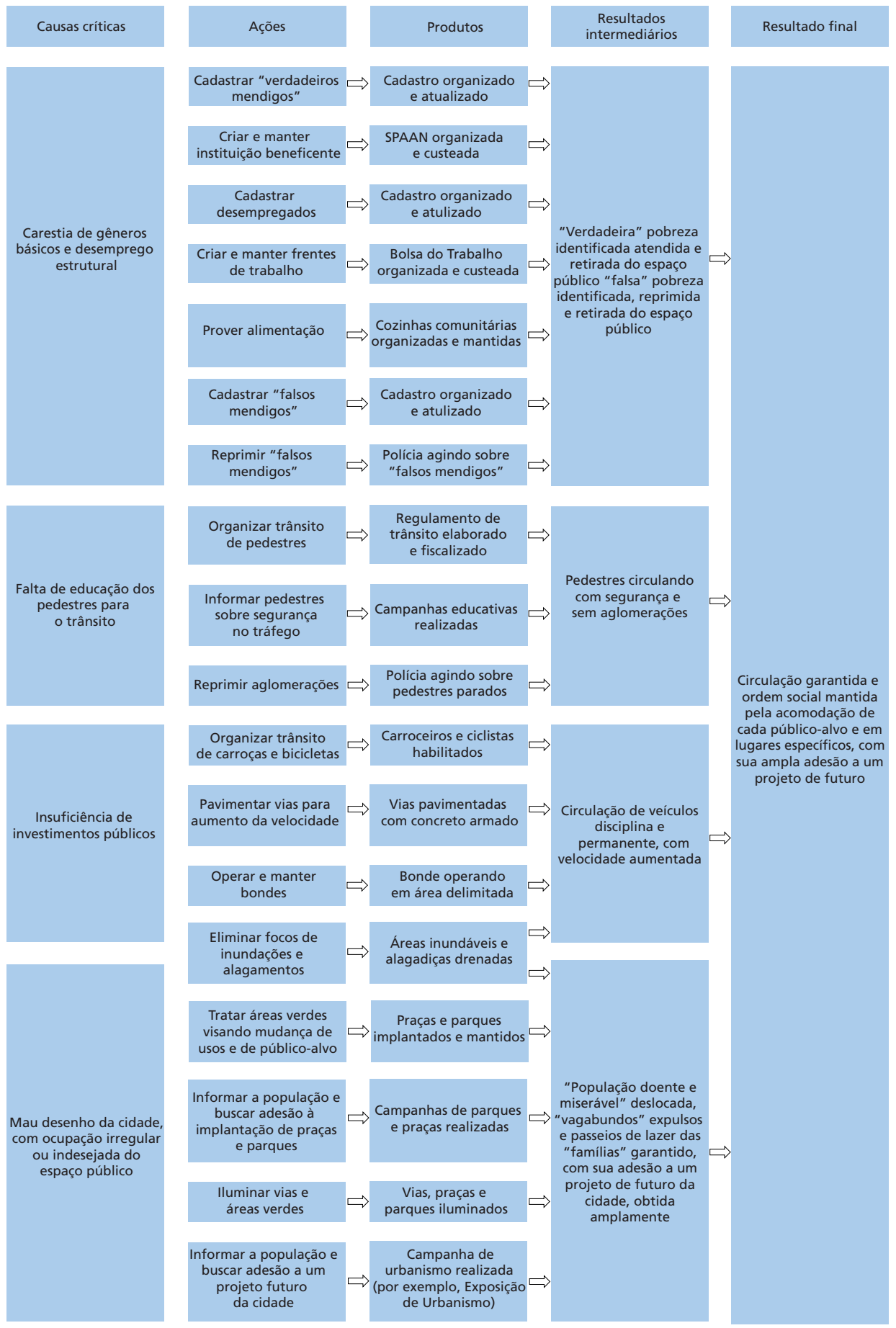

Elaboração do autor. 
Os resultados intermediários referem-se aos mesmos públicos-alvo associados às causas críticas, segmentando-os. A seguir estão as principais ações e produtos associados a cada causa crítica.

- Carestia de gêneros básicos e desemprego estrutural: além das atividades de identificação e cadastramento de cada público-alvo, e da criação de uma instituição responsável pelo atendimento dos verdadeiros mendigos (e pela repressão da polícia aos falsos), já mencionadas, a prefeitura desenvolveu açôes emergenciais para o enfrentamento dos efeitos da crise internacional. Isso se deu com a criação da chamada Bolsa do Trabalho, por meio da qual desempregados foram recrutados para frentes de trabalho, e de cozinhas populares, de modo a prover alimentação para as famílias atingidas. ${ }^{20}$

- Falta de educação dos pedestres para o trânsito: as açóes compreenderam a organizaçáo do trânsito de pedestres, seja por meio de um regulamento e de sua fiscalização, seja por campanhas realizadas pelo Rotary Club. Contudo, também aqui a repressão se fez presente, no sentido de dissolver aglomeraçôes de pedestres na área central da cidade.

- Insuficiência de investimentos públicos: era notória a dificuldade de superar um quadro de carência de recursos próprios e de crédito no pós-1930, de modo que as alternativas encontradas foram no sentido da regulamentação do trânsito de veículos e da manutenção da operaçáo dos bondes em uma área delimitada e sem o crescimento notável da sua rede, reservando-se o efetivo crescimento e melhoria do sistema viário para a tecnologia de pavimentaçáo em concreto armado. Esta, por seu turno, beneficiou mais fortemente a zona suburbana e, portanto, a expansão da cidade, com obras realizadas por meio da coparticipaçáo de proprietários lindeiros, que foram diretamente beneficiados. Não obstante, houve continuidade de obras de drenagem que também criaram condiçôes de tráfego permanente, mas que não conseguiram resolver todos os focos de alagamento e inundaçáo que existiam na zona urbana, até o final do período observado.

- Mau desenho da cidade, com ocupaçáo irregular ou indesejada do espaço público: as campanhas do Rotary Club tiveram uma forte presença entre as açóes associadas a esta causa crítica, especialmente em prol de parques e áreas verdes, visando à mudança

20. A Bolsa do Trabalho foi criada pelo prefeito Alberto Bins em 1930. As obras das frentes de trabalho naquele âmbito incluíram trabalhos de terraplenagem para estradas que dariam acesso a setores afluentes da zona suburbana da cidade. Por sua vez, as cozinhas populares contaram com uma campanha do Rotary Club para que a população não desse esmolas diretamente aos mendigos e, em vez disso, comprasse vales de refeições, de modo a auxiliar o seu funcionamento. 
dos usos até então observados. A prefeitura, por sua vez, responsabilizou-se por iluminar esses espaços públicos. ${ }^{21}$ Quanto ao urbanismo, de modo geral, iniciou-se o desenvolvimento de uma campanha que não se encerraria no período observado, mas que teve a Exposiçáo de Urbanismo de 1936 como ponto alto, no sentido de atingir mais amplamente a população e buscar sua adesão a uma visão (ou projeto) de futuro para a cidade. ${ }^{22}$

O conjunto dos resultados intermediários, se obtido, permitiria produzir o resultado final desejado pelos formuladores da política pública (municipalidade e Rotary Club de Porto Alegre), que incorporaria tanto elementos de circulação como de imobilidade. Se os resultados intermediários englobariam o conjunto de formas disciplinadas de circulação (de pessoas, de veículos e também de ideias, no caso do urbanismo, que entáo se afirmava como disciplina e campo profissional), a manutenção da ordem social, esperada no resultado final, dependeria da acomodação de cada público-alvo ao lugar específico a ele destinado pelo programa. A ampla adesão da população a uma visão de futuro proposta pelo urbanismo, esperada no último resultado intermediário, supondo uma hegemonia não contestada, seria uma coadjuvante para o resultado final.

\subsection{Análise de fatores de contexto}

Por fim, a última etapa do método do modelo lógico foi, de certo modo, realizada no decorrer da própria pesquisa que lhe serve de referência, isto é, uma análise do contexto

21. A importância da iluminação das áreas verdes para um desejado "progresso moral" pode ser inferida a partir de um texto do médico e jornalista carioca Emilio Kemp, que, já em 1927, comparava a reforma urbana de Porto Alegre à do Rio de Janeiro: nas praças "conservadas com esmero e bem iluminadas, o espetáculo repete-se com o mesmo brilho. A vigilância e a claridade dos focos elétricos afugentaram os indesejáveis e seduziram as famílias (...). 0 êxito (...) foi tão completo que o ilustre reformador da cidade já determinou que, em vários arrabaldes, sejam construídas praças de diversões infantis, para que toda a população goze do excelente benefício. Dessa forma influi, diretamente, o [intendente] dr. Otavio Rocha para a modificação da fisionomia moral da metrópole rio-grandense, e completa o plano da sua higienização proporcionando ao público meios de fortalecer a mocidade, recriando-a também" (Kemp, 1927, p. 1).

22. Os comentários de "pessoas notáveis", presentes na Exposição de Urbanismo, registrados pelos mesmos urbanistas que a organizaram (Faria e Paiva, 1938), corroboram uma visão de futuro próspero e desejável para a cidade, caso fossem realizadas as obras por eles propostas. Destaca-se a presença do prefeito, bem como de outros quadros políticos importantes do estado, na abertura e no encerramento da exposição, que teve entre 30 mil ou 50 mil visitantes, conforme a fonte pesquisada, o que corresponderia, respectivamente, a $10 \%$ ou $16 \%$ dos habitantes de Porto Alegre naquele momento. 
relevante em que se aplicaram os melhoramentos urbanos e o urbanismo. ${ }^{23}$ Importa destacar aqui, apenas, os fatores que seriam mais importantes, seja no sentido de contribuírem para que fossem atingidos os resultados, seja no sentido de dificultá-los. Estão listados inicialmente, a seguir, os fatores favoráveis.

- Convergência de interesses entre Estado e elites (a municipalidade e o Rotary Club, neste caso).

- Continuidade administrativa municipal, com melhorias administrativas e fiscais (especialmente após 1925) e tradiçáo de municipalização dos serviços, comandada por uma doutrina baseada nos gastos produtivos do Estado. ${ }^{24}$

- Existência de um campo profissional local preparado para "entregar" as açóes e os produtos previstos ou, ao menos, emprestar legitimidade às soluçóes para as quais seria conveniente um tratamento alegadamente técnico, e não político.

- Existência de capacidade de pagamento de taxas de melhoramentos urbanos por parte dos proprietários de imóveis e prioridade a investimentos reprodutivos, ou seja, solváveis.

- Grande capacidade de pressão dos usuários de automóveis, que reuniam os maiores capitais econômico e cultural.

- Obediência das escolas e de outros "aparelhos de hegemonia" às orientaçóes da classe dominante.

- Disseminação de uma ideologia do trabalho e repúdio geral à ociosidade, à insalubridade e à imoralidade.

- Ocorrência de enchentes (em 1928 e 1936) e seus impactos sobre a circulação e a saúde enquanto justificativa de medidas estruturais pelo poder público, bem como o deslocamento da populaçáo para casas construídas nas partes mais altas e "salubres" da cidade.

23. No Brasil, o urbanismo constitui-se "a partir das experiências de intervenção na cidade que se fazem no terreno da legislação urbanística, do saneamento urbano e dos projetos de abertura e extensão viária", ou seja, a partir dos melhoramentos urbanos, expressão que precede o urbanismo (Leme, 2001, p. 81). Entretanto, o urbanismo passa a incluir visões de futuro, em uma estrutura cognitiva que acrescenta uma psicoesfera às intervenções físicas que já compunham uma tecnoesfera dos melhoramentos urbanos (Krause, 2019). Sobre as noções de tecnoesfera e psicoesfera, ver Santos (2018).

24. Sobre a noção de gastos produtivos do Estado, originada na doutrina do industrialismo de Saint-Simon, ver Harvey (2015). 
- Busca de imitação dos modelos de administração das grandes cidades do país e do exterior.

- Conjuntura política internacional de ameaça como justificativa para medidas locais impositivas e autoritárias.

Os fatores de contexto desfavoráveis seriam de natureza econômica, financeira ou fiscal, conforme descritos a seguir.

- $\quad$ Escassez das fontes de crédito externo.

- Deficit do orçamento municipal.

- Dificuldades de cobrança de taxas extraordinárias (como as relativas à pavimentação viária).

Em uma comparação, os fatores favoráveis teriam sido muito mais numerosos que os desfavoráveis. Estes últimos, por seu turno, poderiam ser atenuados (e o foram) por medidas como a conversão da dívida externa em dívida interna, o aumento da dívida pública pela emissão de apólices ditas populares e a socialização da dívida ativa de proprietários que se beneficiaram diretamente da pavimentação em áreas de expansão na zona suburbana, por renúncia fiscal. ${ }^{25}$ Uma política de classe, portanto, viria a intervir, inserindo conteúdo político-social em um fator de contexto que, a princípio, se mostraria apenas de natureza fiscal.

\section{ANÁLISE DE VULNERABILIDADE DO MODELO LÓGICO DO PROGRAMA DE CIRCULAÇÃO}

Se os fatores favoráveis seriam muito mais numerosos do que os desfavoráveis, o que poderia falhar no programa de circulação? Realiza-se a seguir uma análise de vulnerabilidade, pois, "como não existe o controle das circunstâncias em que o

25. A dívida ativa das contribuições de melhoria da pavimentação nas estradas da zona suburbana era considerável, atingindo, em 1935, valor que equivalia a aproximadamente $20 \%$ da receita orçada do imposto predial naquele ano. Em 1937, foi apresentado na Câmara Municipal projeto de lei que reduzia o prazo e a contribuição dos proprietários beneficiados, de dez para seis anos. Entre seus considerandos, estavam o fato de a prefeitura ter realizado a emissão de apólices em valor inferior ao previsto inicialmente e a avaliação de que, "se é verdade que a obra realizada favoreceu, em parte, os proprietários do arrabalde atingido, não é menos certo, contudo, que todos os outros munícipes dela auferiram vantagens relevantes", de modo que deveria "ser a contribuição respectiva arcada, tanto diretamente pelo proprietário favorecido, como por todos os outros contribuintes indiretamente beneficiados" (Porto Alegre, 1937, p. 320). 0 projeto de lei foi aprovado e, a seguir, sancionado pelo prefeito. 
programa é implementado, é preciso levantar as condiçôes que podem invalidar seu funcionamento esperado" (Cassiolato e Gueresi, 2010, p. 14). Se isso é verdadeiro para um programa implementado no presente, o é ainda mais para um programa hipotético transcorrido no passado. Em contrapartida, é evidente que o recurso a fontes históricas facilita o julgamento do programa, supondo-se que certas informaçóes sobre seu funcionamento não estariam disponíveis à época de sua implementação, mas somente em momento posterior, quando seus efeitos tivessem sido levados em conta na elaboração de conhecimentos sobre o programa.

Destaca-se que um programa de circulação em Porto Alegre teria recorrido em boa medida a açóes que visariam à "educação" dos públicos-alvo. Esta aposta estava baseada na possibilidade de um "progresso moral" da sociedade mediante as diversas formas que a educação, lato sensu, poderia assumir em um governo de inspiração positivista, que, como observado na pesquisa, incluiriam a dispersão de "normas civilizadoras" até mesmo por meio da polícia (Mauch, 1995) - para tanto, esse governo aplicava julgamentos morais em relação aos públicos-alvo da política pública, como visto. A essas normas civilizadoras se juntariam as palestras que sócios do Rotary faziam nas escolas do município e o próprio saber especializado do urbanismo, enquanto conjunto de campanhas voltadas tanto para aspectos particulares da circulação e do uso cotidiano do espaço público, como para uma visão geral do futuro da cidade, apresentada em eventos que também buscaram reforçar a hegemonia do partido no poder, no Rio Grande do Sul e em sua capital. ${ }^{26}$

Contudo, entende-se que as campanhas nem sempre mirariam as causas críticas do problema, podendo focalizar causas remotas - a "índole" moral ou a crise financeira internacional - que não viriam a ser efetivamente transformadas por açóes do programa. Ademais, a própria elaboração do problema urbano em tela teria sido incompleta ao não

26. Um esforço pioneiro de conciliação de partidários do governo e da oposição está expresso no Primeiro Congresso das Municipalidades do Rio Grande do Sul, realizado em julho de 1929. Contemporâneo à criação da Aliança Liberal, com vistas à disputa da presidência da República por Getúlio Vargas, o congresso, além das discussões entre intendentes e representantes do governo estadual, incluiu visitas a obras realizadas em Porto Alegre, fazendo-se "a propaganda e a divulgação das benfeitorias realizadas pelos governos republicanos" (Abreu, 1996, p. 88). Porto Alegre teria tido naquele congresso o melhor exemplo de sua função de "palco de encontros do meio intelectual e político do Estado" (Bakos, 2013, p. 32). As exposições estaduais também seriam utilizadas para "manter o culto ao passado histórico e seus heróis", elegendo-se a data de 20 de setembro como "símbolo do início da Revolução Farroupilha", chegando à sua realização mais significativa em 1935, quando se comemorou o centenário daquele movimento (op. cit., p. 33). A Exposição de Urbanismo de 1936 foi, portanto, tributária desses eventos. 
identificar certas causas que seriam os motivos mais importantes para os comportamentos desaprovados - na representação gráfica do problema (figura 3), buscou-se evidenciar essas lacunas entremeando as causas apuradas.

Com efeito, a pesquisa náo encontrou indícios de que os motivos para os comportamentos indesejados tenham sido levantados pelo Rotary Club ou pela prefeitura. No entanto, é lícito cogitar, por exemplo, a precariedade ou inexistência de passeios (que levariam os pedestres a caminhar no leito das ruas, para fugir de poças de água e da lama), a frequência insuficiente ou irregular do transporte coletivo, especificamente dos bondes que atendiam os bairros operários (o que repercutiria em um comportamento "imprevisível" dos usuários, ao correrem na via de modo a alcançar e embarcar nos veículos em movimento), a inexistência de área pública suficiente para dispersão dos estudantes ao saírem das escolas (e a consequente "invasão" do leito da rua) etc.

Ou seja, haveria certamente mais causas do problema na infraestrutura econômica que não teriam sido levadas em consideração. Edelman (1977, p. 28, tradução nossa) sugere que o motivo para tal acontecimento está nas categorizaçóes do problema, que

implicam que as inadequaçóes dos pobres e o comportamento dos delinquentes podem ser mudados e que as recompensas, puniçóes e tratamentos irão mudá-los; mas o esquema de classificação, por outro lado, define as instituiçóes econômicas como uma parte fixa do cenário, e não como uma questão a ser confrontada.

As inadequaçóes e os comportamentos poderiam ser mudados, mas dificilmente as açóes educativas ou mesmo punitivas levariam a um resultado em curto prazo na "arena da consciência". A própria semântica de campanha denota que se esperaria uma longa duração dessas açóes, de modo que a assertividade e a reiteração de modelos de comportamento levassem à transformaçáo dos indivíduos - no sentido de que os pedestres passariam a circular conforme as regras e os mendigos deixariam "voluntariamente" os passeios, como esperado. Mais do que educaçáo, estava manifesto o desejo de tornar racionais ou, melhor ainda, de automatizar as práticas dos usuários 
do espaço público de Porto Alegre. ${ }^{27}$ Nos termos utilizados à época, resultados que trouxessem melhoramentos materiais seriam, portanto, mais plausíveis e imediatos do que aqueles que implicassem transformaçóes nos comportamentos, e que contribuiriam para o então chamado "progresso moral".

\section{CONSIDERAÇÕES FINAIS SOBRE APLICAÇÕES RETROSPECTIVAS DO MODELO LÓGICO}

Em um exercício investigativo como o aqui apresentado, apoiado integralmente em fontes históricas, cabe uma ressalva epistemológica quanto às hipóteses ou apostas assumidas na representação de uma teoria do programa, tanto do modo como este agiria sobre as causas do problema, como dos relacionamentos entre os componentes de uma estrutura lógica para alcance de resultados.

No caso apresentado, que tratou de melhoramentos urbanos e de urbanismo como aspectos particulares da realidade do capitalismo industrial, é fácil ver que estes situam-se entre categorias: entre a produção e a reproduçấo social, entre o Estado e a sociedade civil, entre a burguesia e os trabalhadores etc. Enquanto problema de pesquisa, esses aspectos da realidade certamente comportam e também exigem atenção a um grande número de fatos de contato e de troca, termo utilizado por Bloch (2001), que, ao reivindicar status de ciência para a história, destaca a importância de estabelecer ligaçôes explicativas entre os fenômenos descritos.

Ainda que haja atenção de qualquer pesquisador no sentido de reunir o maior número de fatos que tenham esses atributos explicativos, não se pode esperar o esgotamento da evidência, ou seja, a prova. Característica da induçáo, esta exige que a descoberta de uma nova evidência invalide o argumento original - entende-se que a expectativa por encontrar novos fatos venha a acarretar, nos termos de que fala Bloch (2001), uma

27. A propósito das práticas, conforme Pierre Bourdieu, uma ideia de racionalidade está na esfera da pré-consciência, o que é fundamental para a noção por ele proposta de habitus, os "sistemas de disposições duráveis" que "são capazes de engendrar, mesmo fora de todo o cálculo consciente, comportamentos e antecipações que vale mais chamar de razoáveis, em vez de racionais" (Bourdieu, 2006, p. 23). Loïc Wacquant detalha o habitus como "noção mediadora que (...) capta (...) o modo como a sociedade torna-se depositada nas pessoas sob a forma de disposições duráveis ou capacidades treinadas e propensões estruturadas para pensar, sentir e agir de modos determinados, que então as guiam em suas respostas criativas aos constrangimentos e solicitações de seu meio social existente" (Wacquant, 2007, p. 65-66). A verdadeira pretensão de um programa de circulação, portanto, antes que de educação, seria de poder intervir nas disposições pré-reflexivas do pensar, do sentir e do agir dos usuários do espaço público. 
atitude de passividade do investigador, retardando a análise. Além disso, um empirismo baseado na exclusão, por meio do esgotamento da evidência, é "oposto a qualquer noção real de honestidade intelectual", sendo que uma anestesia do intelecto pode advir da premissa de "que não se pronuncie nenhum julgamento até que se reúnam todos os fatos" (Sennett, 2011, p. 63, tradução nossa).

Em perspectiva histórica, a verossimilhança empírica é menos ambiciosa, ao declinar de uma análise exaustiva em prol de uma análise razoável. Para Sennett, assim como para Bloch, as ligações explicativas têm importância, pois a verossimilhança "é uma questão de demonstração das conexóes lógicas entre fenômenos que podem ser concretamente descritos" (Sennett, 2011, p. 64, tradução nossa).

Foi esse o caminho seguido na pesquisa aqui relatada e, também, na construção do modelo lógico. Contudo, dadas as dificuldades intransponíveis para reconstituir explicaçóes originais dos formuladores da política pública, exige-se algum relaxamento da infalibilidade de hipóteses de causalidade nesse modelo, seja na explicação de um problema, seja na elaboração de categorizaçóes que sirvam a uma estrutura lógica de açóes, produtos e resultados.

Cabe lembrar que a própria representação das cadeias causais do problema e da estrutura lógica para alcance de resultados, do modo como é feita no modelo aqui em questão, mostra simplificaçóes, uma vez que se expressam de forma linear e unidirecional processos sociais complexos que podem incluir efeitos de retroalimentação, transbordamento etc. Essas representaçóes, no entanto, podem ser enriquecidas, ao agregar-se a elas os conhecimentos que puderem ser obtidos sobre os atos concretos da implementaçáo das políticas públicas, conforme aportados, por exemplo, pelas fontes históricas.

Trata-se, pois, de juntar-se aos esforços por abandonar uma perspectiva tradicional, normativa, de avaliação de resultados e impactos apenas conforme foram definidos em documentos oficiais, uma vez que,

dada a natureza complexa, política e transformadora dos processos de implementação, não só precisamos passar a considerar maiores níveis de incerteza no atingimento de objetivos pretendidos como devemos passar a considerar a emergência de efeitos não pretendidos, [pois], em outras palavras, a implementação necessariamente complica a avaliação dos efeitos (Pires, 2019, p. 19).

Com base na pesquisa realizada, avalia-se que a aplicação da metodologia do modelo lógico em perspectiva histórica permita a inclusão dessas consideraçóes. 


\section{REFERÊNCIAS}

ABREU, L. A. Getúlio Vargas: a construção de um mito (1928-30). Porto Alegre: EdiPUCRS, 1996. BAKOS, M. M. Porto Alegre e seus eternos intendentes. 2. ed. Porto Alegre: EdiPUCRS, 2013. BALBIM, R. et al. Meta-avaliaçáo: estudos e proposiçóes metodológicas a partir da avaliação de políticas de urbanização de assentamentos precários. Rio de Janeiro: Ipea, 2012. (Texto para Discussão, n. 1704).

Metodologia de avaliaçáo de resultados: o caso das intervenções do PAC Urbanização de Favelas. Rio de Janeiro: Ipea, 2013. (Texto para Discussão, n. 1903).

BALBIM, R.; KRAUSE, C. (Ed.). Eixos de Estruturação da Transformação Urbana: inovação e avaliação em São Paulo. Rio de Janeiro: Ipea, 2016.

BECKER, H. S. Trucos del oficio: cómo conducir su investigación en ciencias sociales. Buenos Aires: Siglo XXI, 2011.

BLOCH, M. Apologia da história, ou o ofício de historiador. Rio de Janeiro: Zahar, 2001.

BOURDIEU, P. Introdução. In: BOURDIEU, P. As estruturas sociais da economia. Porto: Campo das Letras, 2006. p. 11-29.

BRASIL. Casa Civil da Presidência da República; IPEA - INSTITUTO DE PESQUISA ECONÔMICA APLICADA. Avaliação de políticas públicas: guia prático de análise ex ante. Brasília: Ipea, 2018. v. 1.

CASSIOLATO, M.; GUERESI, S. Como elaborar modelo lógico: roteiro para formular programas e organizar avaliação. Brasília: Ipea, 2010. (Nota Técnica, n. 6).

EDELMAN, M. Political language: words that succeed and policies that fail. New York: Academic Press, 1977.

FARIA, L. A. U.; PAIVA, E. P. Contribuição ao estudo da urbanização de Porto Alegre. Porto Alegre: Prefeitura Municipal, 1938.

FERREIRA, H.; CASSIOLATO, M.; GONZALEZ, R. Uma experiência de desenvolvimento metodológico para avaliaçáo de programas: o modelo lógico do programa Segundo Tempo. Brasília: Ipea, 2009. (Texto para Discussão, n. 1369).

FREITAS, G.; SILVEIRA, S. F. R. S. Programa Luz para Todos: uma representação da teoria do programa por meio do modelo lógico. Planejamento e Políticas Públicas, Brasília, n. 45, p. 177-198, jul./dez. 2015.

FREY, K. Políticas públicas: um debate conceitual e reflexóes referentes à prática da análise de políticas públicas no Brasil. Planejamento e Políticas Públicas, Brasília, n. 21, p. 211-259, jun. 2000. 
GINZBURG, C. Sinais: raízes de um paradigma indiciário. In: Mitos, emblemas, sinais: morfologia e história. São Paulo: Companhia das Letras, 1989. p. 143-179.

GUERRAND, R.-H. Espaços privados. In: PERROT, M. (Org.). História da vida privada: da Revolução Francesa à Primeira Guerra. São Paulo: Companhia das Letras, 2009. p. 302-385.

HARVEY, D. Paris, capital da modernidade. São Paulo: Boitempo, 2015.

HOFMANN, B. Notas sobre o arruamento de cidades. Revista da Escola de Engenharia de Porto Alegre, Porto Alegre, v. X, n. 1, p. 1-7, jan./fev. 1925.

KEMP, E. Urbs ridens. A Federaçáo, Porto Alegre, 29 jan. 1927. p. 1.

KRAUSE, C. O consenso na prosperidade: melhoramentos urbanos, urbanismo e a estrutura intraurbana em Porto Alegre, 1897-1937. 2019. Tese (Doutorado) - Universidade Federal do Rio de Janeiro, Rio de Janeiro, 2019.

LEME, M. C. S. Urbanismo: a formação de um conhecimento e de uma atuação profissional. In: BRESCIANI, M. S. M. (Org.). Palavras da cidade. Porto Alegre: UFRGS, 2001. p. 77-93.

LOGAN, J. R.; MOLOTCH, H. L. Urban fortunes: the political economy of place. 20th ed. Berkeley: University of California Press, 2007.

MAUCH, C. Policiamento em Porto Alegre nos primórdios da República. In: HAGEN, A. M. M.; MOREIRA, P. R. S. (Org.). Sobre a rua e outros lugares: reinventando Porto Alegre. Porto Alegre: Arquivo Histórico do Rio Grande do Sul; Caixa Econômica Federal, 1995. p. 97-134.

MCLAUGHLIN, J. A.; JORDAN, G. B. Using logic models. In: WHOLEY, J. S.; HATRY, H. P.; NEWCOMER, K. E. (Ed.). Handbook of practical program evaluation. 3rd ed. San Francisco: Jossey-Bass, 2010. p. 55-80.

OLIVEN, R. G. Urbanização e mudança social no Brasil. Petrópolis: Vozes, 1982.

PAIVA, E. P. Expediente urbano de Porto Alegre. Porto Alegre: Prefeitura Municipal, 1942.

PEREIRA, M da S. Localistas e cosmopolitas: a rede do Rotary Club Internacional e os primórdios do urbanismo no Brasil (1905-1935). In: ENCONTRO NACIONAL DA ASSOCIAÇÃO NACIONAL DE PÓS-GRADUAÇÃO E PESQUISA EM PLANEJAMENTO URBANO E REGIONAL, 12., 2007, Belém, Pará. Anais... Belém: ANPUR, 2007. 22 f.

PIRES, R. R. C. (Org.). Implementando desigualdades: reprodução de desigualdades na implementação de políticas públicas. Rio de Janeiro: Ipea, 2019.

PORTO ALEGRE. Anais da Câmara Municipal de Porto Alegre, 1937. Porto Alegre: Livraria do Globo, 1937.

Anais do Arquivo Histórico de Porto Alegre Moysés Vellinho. 2. ed. Porto Alegre: Unidade Editorial da Secretaria Municipal da Cultura, 1996. v. 3. 
REZENDE, V. F. A Era Vargas, o planejamento de cidades e a circulação de ideias: um olhar a partir do Distrito Federal, a cidade do Rio de Janeiro. In: REZENDE, V. F. (Org.). Urbanismo na Era Vargas: a transformação das cidades brasileiras. Niterói: EdUFF; Intertexto, 2012. p. 71-117.

ROMERO, S. O Brasil social. Revista do Instituto Histórico e Geográfico Brasileiro, Rio de Janeiro, v. 114, p. 105-179, 1908.

SAMBUICHI, R. H. R. et al. Programa de Aquisição de Alimentos e segurança alimentar: modelo lógico, resultados e desafios de uma política pública voltada ao fortalecimento da agricultura familiar. Brasília: Ipea, 2019. (Texto para Discussão, n. 2482).

SANTOS, M. A urbanização brasileira. 5. ed. São Paulo: EdUSP, 2018.

SENNETT, R. El declive del hombre público. Barcelona: Anagrama, 2011.

SILVA, F. A. B.; LABREA, V. V. (Org.). Linhas gerais de um planejamento participativo para o programa Cultura Viva. Brasília: Ipea, 2014.

SILVA, J. L.; PAIVA, E. P. Um plano de urbanização. Porto Alegre: Livraria do Globo, 1943.

UMA EXPOSIÇÃO de estudos de urbanismo. A Federação, Porto Alegre, 23 nov. 1936. p. 3.

VEYNE, P. Foucault: o pensamento, a pessoa. Lisboa: Texto e Grafia, 2009.

WACQUANT, L. Esclarecer o habitus. Educação e Linguagem, São Paulo, v. 10, n. 16, p. 63-71, jul./dez. 2007. 
Ipea - Instituto de Pesquisa Econômica Aplicada

Assessoria de Imprensa e Comunicação

\section{EDITORIAL}

Coordenação

Reginaldo da Silva Domingos

\section{Supervisão}

Carlos Henrique Santos Vianna

\section{Revisão}

Bruna Oliveira Ranquine da Rocha

Carlos Eduardo Gonçalves de Melo

Elaine Oliveira Couto

Lis Silva Hall

Mariana Silva de Lima

Marlon Magno Abreu de Carvalho

Vivian Barros Volotão Santos

Laysa Martins Barbosa Lima (estagiária)

\section{Editoração}

Aline Cristine Torres da Silva Martins

Mayana Mendes de Mattos

Louise de Freitas Sarmento (estagiária)

\section{Capa}

Danielle de Oliveira Ayres

Flaviane Dias de Sant'ana

\section{Projeto Gráfico}

Renato Rodrigues Bueno

The manuscripts in languages other than Portuguese published herein have not been proofread.

\section{Livraria Ipea}

SBS - Quadra 1 - Bloco J - Ed. BNDES, Térreo.

70076-900 - Brasília - DF

Fone: (61) 2026-5336

Correio eletrônico: livraria@ipea.gov.br 

Composto em adobe garamond pro 12/16 (texto) Frutiger 67 bold condensed (títulos, gráficos e tabelas) Rio de Janeiro-RJ 



\section{Missão do Ipea}

Aprimorar as políticas públicas essenciais ao desenvolvimento brasileiro por meio da produção e disseminação de conhecimentos e da assessoria ao Estado nas suas decisões estratégicas.

\section{Instituto de Pesquisa Econômica Aplicada}

MINISTÉRIO DA ECONOMIA

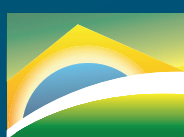

PÁTRIA AMADA BRASIL GOVERNOFEDERAL

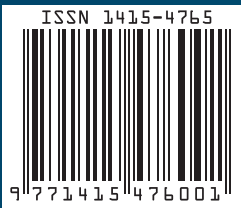

